\title{
Efficacy of a pilot-scale ultrasonication system for pasteurization of milk
}

\author{
Gulsun Akdemir Evrendilek (D) 1*, Anil Bodruk (iD 2,3, Furkan Acar (iD) 2 \\ ${ }^{1}$ Bolu Abant Izzet Baysal University, Faculty of Engineering, Department of Food Engineering, Bolu-Turkey \\ ${ }^{2}$ Pınar Dairy Products Inc., Research and Development Center, Izmir-Turkey \\ ${ }^{3}$ Ege University, Faculty of Engineering, Department of Food Engineering, Izmir- Turkey
}

\begin{abstract}
This study aimed to test a pilot-scale continuous ultrasonication (US) system to pasteurize whole milk in terms of its properties, energy consumption, and inactivation of alkaline phosphatase (ALP), total mesophilic aerobic bacteria (TMAB), total coliform (TC), total Enterobactericeae (TE), and Escherichia coli. Except for those treated by $90 \%$ amplitude for 20 and $30 \mathrm{~min}$, the samples were found negative for ALP activity. US processing with different amplitude, temperature, and treatment time provided significant inactivation on the mean initial numbers of TC, TMAB, TE, and E. coli. The maximum cost was estimated for the US system and plate heat exchanger to pasteurize $20.000 \mathrm{~L}$ milk as $2.778,00 €$ and 3.624,00 €, respectively. $96.52 \%$ amplitude, $40 \mathrm{~min}$, and $53.50{ }^{\circ} \mathrm{C}$ were determined jointly as the optimal operational settings.
\end{abstract}

\section{ARTICLE HISTORY}

Received: 2 October 2021

Accepted: 27 October 2021

\section{KEYWORDS \\ Ultrasonication \\ Milk processing \\ Optimization \\ Alkaline phosphatase \\ Cost analyses}

\section{* CORRESPONDING}

gevrendilek@ibu.edu.tr

\section{Introduction}

Due to its high water activity and lower acidity, milk is excellent medium for spoilage microorganisms and foodborne pathogens as well as enzymes causing deterioration. Although the thermal treatment of milk from pasteurization to ultra-high temperature (UHT) provides the inactivation of microorganisms and enzymes, recent concerns have been with both its safety and the preservation of its physical, nutritional, and sensory properties. The thermal treatment was reported to decrease its folic acid content and adversely affect its color, aroma, and odor (Pegu and Arya, 2021; Prasantha and Wimalasiri, 2019). Ultrasonication (US), as a novel processing technology, has emerged as an alternative to the heat processing of milk. US with frequencies of 20-100 kHz and energy intensities of 10$100 \mathrm{kHz} \mathrm{W} \mathrm{cm}_{-2}$ generates acoustic cavitation, and thus, a localized pressure of 100-5000 bar with a high temperature of $500-15000 \mathrm{~K}$. Free radicals, shockwaves, liquid microjets, and interfacial turbulence are formed by the collapse of cavities (Carpenter et al., 2016; Gogate and Pandit, 2001), thus pasteurizing liquid foods (Asaithambi et al., 2019; Milly et al., 2007; Milly et al., 2008). Depending on the US intensity, the treatment disrupts casein micelles and milk fat globules (Martini, 2013) and reduces their size (Nguyen and Anema, 2017; 2010). Also, whey proteins undergo partial cleavage on hydrophobic interactions (Chandrapala et al., 2012).
In related literature, there still exists a knowledge gap about how the US processing impacts whole milk. Thus, the objectives of the study were to (1) determine changes in technological properties, microbial inactivation, and energy consumption in response to the US processing of whole milk; and (2) jointly optimize the process parameters.

\section{Materials and methods}

\subsection{Materials}

Raw milk was purchased from local producers and brought to Pinar Dairy Products Inc. (Izmir, Turkey) in cold chain. All milk samples were kept at $4{ }^{\circ} \mathrm{C}$ until processing.

2.2. Pilot-scale ultrasonic system

A pilot-scale ultrasonic system; BSP-1200 Ultrasonic Processor (Sonomechanics, Florida, USA) was used to process milk samples. The system generates $1200 \mathrm{~W}$ ultrasonic waves with a piezoelectric transducer. The detailed scheme of the system is given in Figure 1.

The system properties are: maximum $500 \mathrm{~L} \mathrm{~h}^{-1}$ flow rate, $1200 \mathrm{~W}$ ultrasonic power generation, $20 \mathrm{kHz}$ work frequency, 20-100\% amplitude, and cooling-heating chamber cooperated with ultrasonic temperature range of 15$100^{\circ} \mathrm{C}$. The fluid material can be heated or cooled to provide optimum condition before feeding and is continuously ultrasonicated at an optimum temperature. Milk was heated or cooled in the system at a desired treatment temperature. Ultrasonication process $(200 \mathrm{kHz}, 700 \mathrm{~W})$ was applied using 
the three amplitudes $(90,95$, and $100 \%)$, six temperatures $\left(40,45,50,53,55\right.$, and $\left.57^{\circ} \mathrm{C}\right)$, and three durations $(20,30$, and $40 \mathrm{~min})$.

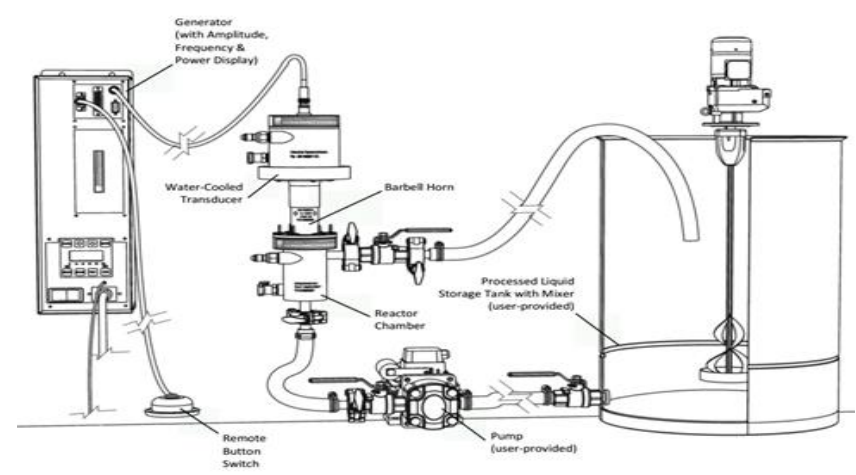

Figure 1. Pilot scale continuous ultrasonic system scheme

\subsection{Approximate composition analysis}

Protein, fat, and non-fat dry matter content were determined using a Milkoscan FT1 (MilkoScan, Hillerød, Denmark). Results were expressed as amount \% in milk.

\section{$2.4 \mathrm{pH}$ measurement}

$\mathrm{pH}$ was measured at room temperature using a WTW ProfiLine pH 3110 (Germany).

\subsection{Viscosity measurement}

Viscosity of the milk samples was determined using a DV-1 model Brookfield Digital Viscometer (Brookfield Engineering Labs Inc.).

\subsection{Alkaline phosphatase analysis}

Alkaline phosphatase (ALP) activity was measured using a Sensobiz ${ }^{\circledR}$ (Ankara, Turkey) sensor.

\subsection{Microbiological analysis}

Total Enterobacteriaceae (TE), total coliform (TC), and Escherichia coli were enumerated according to the Anonymous (2016) method. Total mesophilic aerobic bacteria (TMAB) count was performed using ISO 4833-1 (2013).

\subsection{Energy consumption}

Energy consumption ( $\mathrm{kWh}$ ) of the US system was measured using a TT T-ECHNI-C Watt meter (Acrel, Shanghai, China). Heat treatment performed at $72^{\circ} \mathrm{C}$ for $15 \mathrm{sec}$ was used for energy calculation.

\subsection{Statistical analysis}

One-way analysis of variance (ANOVA) followed by Tukey's multiple comparison tests were conducted (Minitab 17, Minitab, Inc., State College, PA) for determination of differences among the treatments. The best-fit artificial neural network (ANN) was constructed to predict (1) the multiple responses of microbial inactivation as a function of amplitude, treatment time, and treatment temperature. The activation function of the hyperbolic tangent (TanH) (a sigmoid function), one hidden layer with seven neurons, a learning rate of 0.1 , and a squared penalty method were selected in the ANN through a trial-and-error approach by monitoring the improvements on RMSE and R2 values based on a random 5-fold cross-validation. The joint optimization was based on the composite desirability (D) of 0 to 1 (optimal). The simultaneous optimization was implemented using the best-fit ANN according to the target function of minimization for the responses. Interaction effect and predictor importance were determined using the Monte Carlo simulation of independent resampling. All the analyses were performed using JMP Pro 16.

\section{Results and discussions}

Initial trials were conducted with different amplitudes, temperatures, and sonication times to determine the processing parameters for milk pasteurization. Regardless of the treatment temperature and time, the amplitudes of 70$85 \%$ were not effective for microbial inactivation. The treatments conducted with 90, 95, and 100\% amplitudes were effective for both microbial and ALP inactivation. Similarly, since the treatment times below 20 min were not effective, the experimental design in Table 1 was applied after the initial runs.

The temperature increased slightly during the US processing. With application of different amplitude and treatment times, the processing temperature varied between $42{ }^{\circ} \mathrm{C}$ with $90 \%$ amplitude for both 20 and 30 min and 61 ${ }^{\circ} \mathrm{C}$ with $100 \%$ amplitude for $40 \mathrm{~min}$. $\mathrm{pH}$ of the control samples $(6.68 \pm 0.04)$ ranged from $6.61 \pm 0.10$ with $100 \%$ amplitude for $40 \mathrm{~min}$ to $6.70 \pm 0.07$ with $90 \%$ amplitude for 20 min. Fat $(3.58 \pm 0.04 \%)$ content of the samples changed from $3.50 \pm 0.06$ with $100 \%$ for $30 \mathrm{~min}$ to $3.67 \pm 0.06$ with $90 \%$ amplitude for $30 \mathrm{~min}$; whereas protein $(3.18 \pm 0.06 \%)$ content of the samples changed from $3.10 \pm 0.07 \%$ with $100 \%$ amplitude for $40 \mathrm{~min}$ to $3.26 \pm 0.08$ with $90 \%$ amplitude for $30 \mathrm{~min}$, respectively. Viscosity of the control samples $(0.062 \pm 0.06 \mathrm{~kg} \mathrm{~ms}-1)$ was in the range of $0.062 \pm$ 0.07 by $90 \%$ amplitude for $20 \mathrm{~min}$ at $42{ }^{\circ} \mathrm{C}$ and $0.071 \pm 0.08$ by $100 \%$ amplitude for $40 \mathrm{~min}$ at $61{ }^{\circ} \mathrm{C}$ (Table 1). Overall, the applied US parameters did not cause significant changes in the $\mathrm{pH}$, TSS, viscosity, and approximate composition of whole milk $(\mathrm{p}>0.05)$.

Efficacy of the US processing on milk properties significantly depended on the applied processing parameters. The US processing by 200,300 , and $400 \mathrm{~W}$ for 4,6 , and 8 min slightly increased the total soluble solid (TSS) and viscosity of the control samples. The cavitation effect of the US treatment increased TSS, and thus, the viscosity. The increased viscosity can be also related to the increased number of fat globules due to the size reduction and casein adsorption on their surface (McSweeney and Fox, 2009; Pegu and Arya, 2021). The combination of US with the preheat treatment increased the heat stability of the dairy ingredients and gelling properties (Ashokkumar et al., 2010; Pegu and Arya, 2021). No significant difference was reported for the protein or lactose content of the raw and pasteurized milk processed by 2.5, 5.0, 6.0, 7.5 and $10.0 \mathrm{~min}$ at $100 \%$ amplitude (Cameron et al., 2010).

Except for those treated by $90 \%$ amplitude for 20 and 30 min at $42{ }^{\circ} \mathrm{C}$, the samples were found negative for ALP activity. An increase in both amplitude and temperature provided inactivation on ALP activity (Table 1). ALP, naturally occurring endogenous enzyme of raw milk, is bound to membranes of fat globules (Griffiths, 1986; Shamsi et al., 2008). As a heat sensitive enzyme, its denaturation occurs during the heat treatment at $56{ }^{\circ} \mathrm{C}$ for $30 \mathrm{~min}$. 
Table 1. Ultrasonication treatments of raw milk

\begin{tabular}{|c|c|c|c|c|c|c|c|c|c|}
\hline Amplitude (\%) & $\begin{array}{l}\text { Treatment } \\
\text { time (min) }\end{array}$ & $\begin{array}{c}\text { Temperature } \\
\left({ }^{\circ} \mathrm{C}\right)\end{array}$ & $\begin{array}{c}\text { US sample } \\
\text { temperature } \\
\left({ }^{\circ} \mathrm{C}\right)\end{array}$ & $\begin{array}{l}\text { Fat } \\
(\%)\end{array}$ & $\begin{array}{c}\text { Protein } \\
(\%)\end{array}$ & $\begin{array}{c}\text { Alkaline } \\
\text { phosphatase } \\
\text { activity }\end{array}$ & $\mathrm{pH}$ & $\begin{array}{c}\text { Non-fat dry } \\
\text { matter }\end{array}$ & $\begin{array}{l}\text { Viscosity } \\
\left(\mathrm{kg} \mathrm{ms}^{-1}\right)\end{array}$ \\
\hline 0 & 0 & 4 & 4 & $3.58 \pm 0.04^{\mathrm{ab}}$ & $3.18 \pm 0.06^{\mathrm{a}}$ & + & $6.68 \pm 0.04^{\mathrm{a}}$ & $8.31 \pm 0.76^{\mathrm{a}}$ & $0.062 \pm 0.06^{\mathrm{a}}$ \\
\hline 90 & 20 & 40 & 42 & $3.61 \pm 0.01^{\mathrm{ab}}$ & $3.11 \pm 0.09^{\mathrm{a}}$ & + & $6.66 \pm 0.06^{\mathrm{a}}$ & $8.29 \pm 0.82^{\mathrm{a}}$ & $0.062 \pm 0.07^{\mathrm{a}}$ \\
\hline 90 & 30 & 40 & 42 & $3.60 \pm 0.02^{\mathrm{ab}}$ & $3.14 \pm 0.06^{\mathrm{a}}$ & + & $6.67 \pm 0.04^{\mathrm{a}}$ & $8.40 \pm 0.90^{\mathrm{a}}$ & $0.064 \pm 0.08^{\mathrm{a}}$ \\
\hline 90 & 20 & 45 & 47 & $3.60 \pm 0.03^{\mathrm{ab}}$ & $3.13 \pm 0.08^{\mathrm{a}}$ & - & $6.66 \pm 0.04^{\mathrm{a}}$ & $8.06 \pm 0.68^{\mathrm{a}}$ & $0.069 \pm 0.08^{\mathrm{a}}$ \\
\hline 90 & 30 & 45 & 49 & $3.67 \pm 0.06^{\mathrm{ab}}$ & $3.12 \pm 0.08^{\mathrm{a}}$ & - & $6.66 \pm 0.06^{\mathrm{a}}$ & $7.97 \pm 0.80^{\mathrm{a}}$ & $0.068 \pm 0.07^{\mathrm{a}}$ \\
\hline 90 & 20 & 50 & 53.1 & $3.61 \pm 0.02^{\mathrm{a}}$ & $3.25 \pm 0.10^{\mathrm{a}}$ & - & $6.70 \pm 0.07^{\mathrm{a}}$ & $7.94 \pm 0.69^{\mathrm{a}}$ & $0.066 \pm 0.08^{\mathrm{a}}$ \\
\hline 90 & 30 & 50 & 54.6 & $3.58 \pm 0.03^{\mathrm{ab}}$ & $3.26 \pm 0.08^{\mathrm{a}}$ & - & $6.69 \pm 0.06^{\mathrm{a}}$ & $8.03 \pm 0.58^{\mathrm{a}}$ & $0.069 \pm 0.09^{\mathrm{a}}$ \\
\hline 95 & 20 & 50 & 52.8 & $3.52 \pm 0.03^{\mathrm{b}}$ & $3.22 \pm 0.08^{\mathrm{a}}$ & - & $6.64 \pm 0.08^{\mathrm{a}}$ & $8.16 \pm 0.46^{\mathrm{a}}$ & $0.066 \pm 0.08^{a}$ \\
\hline 95 & 30 & 50 & 54.2 & $3.52 \pm 0.02^{\mathrm{b}}$ & $3.22 \pm 0.09^{\mathrm{a}}$ & - & $6.65 \pm 0.08^{\mathrm{a}}$ & $8.07 \pm 0.48^{\mathrm{a}}$ & $0.065 \pm 0.07^{\mathrm{a}}$ \\
\hline 95 & 20 & 53 & 55.5 & $3.64 \pm 0.03^{\mathrm{a}}$ & $3.18 \pm 0.06^{\mathrm{a}}$ & - & $6.63 \pm 0.10^{\mathrm{a}}$ & $7.96 \pm 0.56^{\mathrm{a}}$ & $0.066 \pm 0.07^{\mathrm{a}}$ \\
\hline 95 & 30 & 53 & 58 & $3.57 \pm 0.04^{\mathrm{a}}$ & $3.19 \pm 0.08^{\mathrm{a}}$ & - & $6.68 \pm 0.07^{\mathrm{a}}$ & $8.11 \pm 0.70^{\mathrm{a}}$ & $0.063 \pm 0.05^{a}$ \\
\hline 95 & 20 & 55 & 57 & $3.62 \pm 0.03^{\mathrm{a}}$ & $3.24 \pm 0.06^{\mathrm{a}}$ & - & $6.65 \pm 0.05^{\mathrm{a}}$ & $8.04 \pm 0.67^{\mathrm{a}}$ & $0.066 \pm 0.07^{a}$ \\
\hline 100 & 30 & 50 & 54 & $3.53 \pm 0.03^{\mathrm{ab}}$ & $3.16 \pm 0.06^{\mathrm{a}}$ & - & $6.67 \pm 0.06^{\mathrm{a}}$ & $8.07 \pm 0.71^{\mathrm{a}}$ & $0.068 \pm 0.05^{a}$ \\
\hline 100 & 40 & 50 & 55 & $3.53 \pm 0.02^{\mathrm{ab}}$ & $3.10 \pm 0.07^{\mathrm{a}}$ & - & $6.66 \pm 0.04^{\mathrm{a}}$ & $8.15 \pm 0.80^{\mathrm{a}}$ & $0.063 \pm 0.09^{a}$ \\
\hline 100 & 30 & 53 & 57 & $3.50 \pm 0.06^{\mathrm{ab}}$ & $3.21 \pm 0.06^{\mathrm{a}}$ & - & $6.68 \pm 0.12^{\mathrm{a}}$ & $8.02 \pm 0.77^{\mathrm{a}}$ & $0.065 \pm 0.07^{a}$ \\
\hline 100 & 40 & 53 & 58 & $3.52 \pm 0.07^{\mathrm{ab}}$ & $3.21 \pm 0.08^{\mathrm{a}}$ & - & $6.63 \pm 0.10^{\mathrm{a}}$ & $7.90 \pm 0.65^{\mathrm{a}}$ & $0.068 \pm 0.05^{a}$ \\
\hline 100 & 30 & 55 & 59 & $3.52 \pm 0.06^{\mathrm{ab}}$ & $3.22 \pm 0.09^{\mathrm{a}}$ & - & $6.65 \pm 0.09^{\mathrm{a}}$ & $7.96 \pm 0.66^{\mathrm{a}}$ & $0.064 \pm 0.07^{a}$ \\
\hline 100 & 40 & 55 & 60 & $3.52 \pm 0.02^{\mathrm{ab}}$ & $3.22 \pm 0.06^{\mathrm{a}}$ & - & $6.63 \pm 0.08^{\mathrm{a}}$ & $7.98 \pm 0.59^{\mathrm{a}}$ & $0.069 \pm 0.06^{a}$ \\
\hline 100 & 30 & 57 & 60 & $3.63 \pm 0.03^{\mathrm{ab}}$ & $3.20 \pm 0.06^{\mathrm{a}}$ & - & $6.68 \pm 0.08^{\mathrm{a}}$ & $8.03 \pm 0.66^{\mathrm{a}}$ & $0.070 \pm 0.08^{a}$ \\
\hline 100 & 40 & 57 & 61 & $3.63 \pm 0.06^{\mathrm{ab}}$ & $3.19 \pm 0.08^{\mathrm{a}}$ & - & $6.61 \pm 0.10^{\mathrm{a}}$ & $8.07 \pm 0.70^{\mathrm{a}}$ & $0.071 \pm 0.08^{a}$ \\
\hline
\end{tabular}


Thus, ALP, as a universal indicator of high temperature short time (HTST) pasteurization, is generally used for the thermal processing (Pegu and Arya, 2021). The US processing was also effective for ALP inactivation, and a $14 \%$ reduction was obtained at $400 \mathrm{~W}$ for $8 \mathrm{~min}$ (Pegu and Arya, 2021). Changes in enzyme activity is related to disruptions on hydrogen bonds and van der Waals interactions in the polypeptide structure (Munir et al., 2019). Denaturation rate of ALP increased with the extension of exposure time and intensity as more bubble formation and collapsing were both favored with local hotspots and micromechanical shock. Temperature increase as a result of increase in exposure time and intensity has an important role in denaturation of ALP activity (Pegu and Arya, 2021). US processing parameters of $2.5,5.0,6.0,7.5$ and $10.0 \mathrm{~min}$ at $100 \%$ amplitude, on the other hand, were not effective for the deactivation of alkaline phosphatase and lactoperoxidase activities (Cameron et al., 2010).

The mean initial TE, TC, TMAB, and total Escherichia coli counts were $5.38 \pm 0.45,5.41 \pm 0.37,6.02 \pm 0.00$, and $7.81 \pm 0.36 \log$ cfu $\mathrm{mL}-1$, respectively. A complete inactivation was observed for TE, TC, and total E. coli counts with $100 \%$ amplitude for both 30 and $40 \mathrm{~min}$ at 57.0 ${ }^{\circ} \mathrm{C}$. The mean initial TMAB count reduced to $2.12 \pm 0.08 \mathrm{log}$ cfu mL-1 under the same processing conditions (Figure 2).
The processing of whole milk at $24 \mathrm{kHz}$ for $0,2,4,8$, and 16 min provided a $1 \log$ reduction in the total viable count (TVC) while a $1.5 \mathrm{log}$ reduction in psychrotrophic counts (PC) was achieved only after $16 \mathrm{~min}$, respectively (Chouliara et al., 2010). Similarly, TVC fell by $0.2,0.6$, and 2.9 logs after the continuous flow US process with the increased temperatures of $48.6,62$, and $76{ }^{\circ} \mathrm{C}$, respectively (De Jong and Villamiel, 2000). The US processing at 200, 300, and $400 \mathrm{~W}$ for 4,6 , and 8 min resulted in $0.73 \log$ reduction in total psychotrophic count and $0.79 \log$ reduction in yeast and mold count after $400 \mathrm{~W}$ for 8 min (Pegu and Arya, 2021). It has been reported that microbial inactivation obtained by US can be provided by cavitation having mechanical effect including shear stress, generation of turbulence, shock waves, and liquid jet; chemical effect including generation of free radicals; and thermal effects including creation of local high-temperature (Asaithambi et al., 2019; Salve et al., 2019; Tao et al., 2009). Microbial inhibition provided by US depends on free radical formation occurred by the disruption of chemical bonds and oxidation reactions in the bubbleliquid interface of the bulk liquid resulting with the cell membrane disruption and microbial inactivation (BermúdezAguirre et al., 2011). US processing of milk $\left(41^{\circ} \mathrm{C}\right)$ at 0,108 and $216 \mu \mathrm{m}$ amplitudes for 3 min provided $0.64,0.53$ and $3.37 \log$ inactivations, respectively (Ganesan et al., 2015).
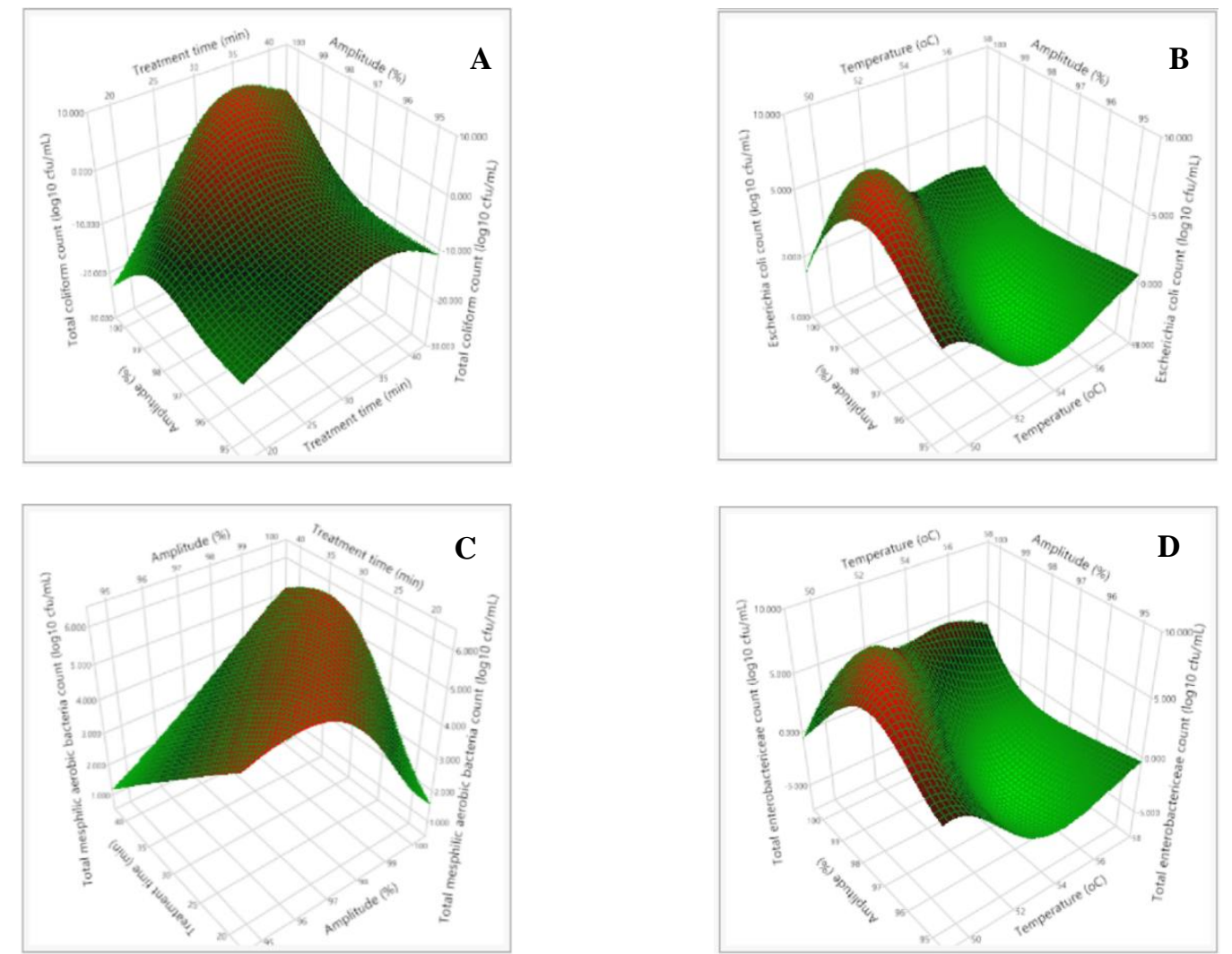

Figure 2. Microbial inactivation by US processing parameters. Inactivation of A) total coliform B) Escherichia coli, C) Total mesophilic aerobic bacteria, and D) Total Enterobactericeae as a function of amplitude and treatment time

Increased US processing temperature to $72{ }^{\circ} \mathrm{C}$ at $180 \mu \mathrm{m}$ amplitude with processing times of 1 and 5 min resulted in 3.04 and $4.28 \mathrm{log}$ reductions, respectively (Pegu and Arya, 2021). The processing of raw milk by US with 200,300 , and
$400 \mathrm{~W}$ for 4,6 , and $8 \mathrm{~min}$ resulted in 0.9 and $0.7 \log$ reductions on total plate count and total yeast and mold count (Pegu and Arya, 2021). 
Table 2. Energy constumption and cost of pasteurization of milk by ultrasonication process.

\begin{tabular}{|c|c|c|c|c|c|c|c|c|}
\hline $\begin{array}{c}\text { Amplitude } \\
(\%)\end{array}$ & $\begin{array}{l}\text { Treatment } \\
\text { time }(\mathrm{min})\end{array}$ & $\begin{array}{c}\text { Temperature } \\
\left({ }^{\circ} \mathrm{C}\right)\end{array}$ & $\begin{array}{c}\text { Energy } \\
\text { consumption } \\
(\mathrm{kW})\end{array}$ & $\begin{array}{c}\text { Cost } \\
(€)\end{array}$ & $\begin{array}{l}\text { Energy } \\
\text { Need of } \\
1 \mathrm{~L} \mathrm{milk} \\
(\mathrm{kW})\end{array}$ & $\begin{array}{l}\text { Cost of } 1 \mathrm{~L} \\
\text { milk } \\
\text { processing } \\
(€)\end{array}$ & $\begin{array}{c}\text { Pasteurization } \\
\text { cost of } 20.000 \mathrm{~L} \\
\text { milk }(€)\end{array}$ & $\begin{array}{l}\text { Pasteurization } \\
\text { cost of } 20.000 \mathrm{~L} \\
\text { milk with HTST } \\
(€)\end{array}$ \\
\hline 90 & 20 & 50 & 0.170 & 0.0085 & 0.00185 & 0.000096 & 2.564 & 3.624 \\
\hline 90 & 30 & 50 & 0.254 & 0.0126 & 0.00185 & 0.000096 & 2.564 & 3.624 \\
\hline 95 & 20 & 45 & 0.172 & 0.0086 & 0.00185 & 0.000096 & 2.564 & 3.624 \\
\hline 95 & 30 & 45 & 0.258 & 0.0124 & 0.00185 & 0.000096 & 2.564 & 3.624 \\
\hline 95 & 20 & 53 & 0.175 & 0.0087 & 0.00185 & 0.000096 & 2.564 & 3.624 \\
\hline 95 & 30 & 53 & 0.263 & 0.0126 & 0.00185 & 0.000096 & 2.564 & 3.624 \\
\hline 95 & 20 & 56 & 0.178 & 0.0089 & 0.00185 & 0.000096 & 2.564 & 3.624 \\
\hline 95 & 30 & 56 & 0.267 & 0.0134 & 0.00185 & 0.000096 & 2.564 & 3.624 \\
\hline 100 & 30 & 57 & 0.27 & 0.0136 & 0.00191 & 0.000128 & 2.695 & 3.624 \\
\hline 100 & 40 & 57 & 0.272 & 0.0142 & 0.00191 & 0.000130 & 2.778 & 3.624 \\
\hline
\end{tabular}

Energy consumption and cost of US and heat pasteurization are given in Table 2. Energy consumption by US was changed by the applied amplitude, treatment time and temperature. Cost of milk pasteurization by US changed from $2.564 €$ to $2.778 €$ for $100 \%$ amplitude, $40 \mathrm{~min}$ treatment time at $57{ }^{\circ} \mathrm{C}$ treatment temperature; whereas it was calculated as $3.624 €$ for HTST treatment $\left(72^{\circ} \mathrm{C}\right.$ for 15 $\mathrm{sec})$. The energy cost of the US processing was lower than that of the heat pasteurization. Similar to present study, it is also reported that ultrasound provides significant energy saving than that of the heat treatment even though US processing takes longer time than that of the HTST process (Chemat et al., 2011; Gogate and Pandit, 2001).

The joint optimization showed $96.52 \%, 40 \mathrm{~min}$, and $53.50{ }^{\circ} \mathrm{C}$ as the optimal processing parameters $(\mathrm{D}=0.995)$. Amplitude, temperature and treatment time were the main effects with for the inactivation of TE, TC, E. coli and TMAB, with amplitude and temperature having greater impact on microbial inactivation.

\section{Conclusion}

A continuous pilot-scale US processing of whole milk with 90, 95 and $100 \%$ amplitude, 20, 30, and $40 \mathrm{~min}$, and 45, 45, $50,53,55$, and $57^{\circ} \mathrm{C}$ did not adversely affect $\mathrm{pH}$, non-fat dry matter, and fat and protein contents of whole milk. Overall, the applied US processing parameters were successful on the denaturation of ALP enzymes, except the samples treated by $90 \%$ for 20 and $30 \mathrm{~min}$ at $42{ }^{\circ} \mathrm{C}$. The initial numbers of $\mathrm{E}$. coli, TMAB, and TE significantly decreased with the US processing $(\mathrm{p}<0.05) .96 .52 \%, 40 \mathrm{~min}$, and $53.50{ }^{\circ} \mathrm{C}$ were the optimal operational conditions with 0.995 desirability. The US processing unit was comparable to the HTST processing in terms of energy efficacy and cost. The maximum cost was estimated at $2.778 €$ for the US processing at the highest amplitude and temperature as well as the longest treatment time and at $3.624 €$ for the HTST unit to pasteurize $20.000 \mathrm{~L}$ of milk. This study was conducted to determine effect of pilot-scale US system on microbial inactivation and some properties of raw milk; but it is also important to investigate effect of US on properties of cheese made from US-treated milk. Moreover, further studies need to be conducted to determine the effect of the pilot-scale US system on protein denaturation, sensory analyses, nutritional content, and shelf-life extension of milk in comparison with the HTST processing.

\section{Compliance with Ethical Standards}

\section{Conflict of Interest}

The authors declare that they have no conflict of interest.

\section{Authors' Contributions}

Gulsun Akdemir Evrendilek: Project administration, data analyses, writing manuscript. Anil Bodruk: Data collection, project administration, editing manuscript. Furkan Acar: Data collection, conducting test and analyses, editing manuscript. All authors accepted the manuscript.

\section{Ethical approval}

Not applicable.

\section{Funding}

No financial support was received for this study.

\section{Data availability}

Not applicable.

\section{Consent for publication}

Not applicable.

\section{Acknowledgements}

The authors would like to thank TUBITAK-TEYDEP (Project no 3170830) for financial support.

\section{References}

Anonymous. (2016). EN ISO 16140-1 Microbiology of the Food Chain-Method Validation- Part 1: Vocabulary. International Organization for Standardization, Geneva, Switzerland.

Asaithambi, N., Singha, P., Dwivedi, M., \& Singh, S.K. (2019). Hydrodynamic cavitation and its application in food and beverage industry: A review. Journal of Food Process Engineering, 42(5), e13144. https://doi.org/10.1111/jfpe.13144 Ashokkumar, M., Bhaskaracharya, R., Kentish, S., Lee, J., Palmer, M., \& Zisu, B. (2010). The ultrasonic processing of dairy products-An overview. Dairy Science \& Technology, 90(2): 147-168. https://doi.org/10.1051/dst/2009044

Bermúdez-Aguirre, D., Mobbs, T., \& Barbosa-Cánovas, G.V. (2011). Ultrasound Applications in Food Processing. In H. Feng, G. Barbosa-Canovas, \& J. Weiss (Eds.), Ultrasound Technologies for Food and Bioprocessing (pp. 65-105). Springer. https://doi.org/10.1007/978-1-4419-7472-3_3

Cameron, M., McMaster, L.D., \& Britz, T.J. (2010). Impact of ultrasound on dairy spoilage microbes and milk components. 
Dairy Science \& Technology, 90(1), 119-119. https://doi.org/10.1051/dst/2010003

Carpenter, J., Badve, M., Rajoriya, S., George, S., Saharan, V., \& Pandit, A. (2016). Hydrodynamic cavitation: An emerging technology for the intensification of various chemical and physical processes in a chemical process industry. Reviews in Chemical Engineering, 33. https://doi.org/10.1515/revce-20160032

Chandrapala, J., Martin, G.J.O., Zisu, B., Kentish, S.E., \& Ashokkumar, M. (2012). The effect of ultrasound on casein micelle integrity. Journal of Dairy Science, 95(12), 6882-6890. https://doi.org/10.3168/jds.2012-5318

Chemat, F., Zill-e-Huma, \& Khan, M.K. (2011). Applications of ultrasound in food technology: Processing, preservation and extraction. Ultrasonics Sonochemistry, 18(4), 813-835. https://doi.org/10.1016/j.ultsonch.2010.11.023

Chouliara, E., Georgogianni, K.G., Kanellopoulou, N., \& Kontominas, M.G. (2010). Effect of ultrasonication on microbiological, chemical and sensory properties of raw, thermized and pasteurized milk. International Dairy Journal, 20(5): 307-313. https://doi.org/10.1016/j.idairyj.2009.12.006

De Jong, P., \& Villamiel, M. (2000). Inactivation of Pseudomonas flourescens and Streptococcus thermophilus in trypticase soy broth and total bacteria count in milk by continuous-flow ultrasonic treatment and conventional heating. Journal of Food Engineering, 45, 171-179. https://doi.org/10.1016/S02608774(00)00059-5

Ganesan, B., Martini, S., Solorio, J., \& Walsh, M.K. (2015). Determining the effects of high intensity ultrasound on the reduction of microbes in milk and orange juice using response surface methodology. International Journal of Food Science, 2015, 1-7. https://doi.org/10.1155/2015/350719

Gogate, P., \& Pandit, A. (2001). Hydrodynamic cavitation reactors: A state of the art review. Reviews in Chemical Engineering, 17, 1-85. https://doi.org/10.1515/REVCE.2001.17.1.1

Griffiths, M. W. (1986). Use of milk enzymes as indices of heat treatment. Journal of Food Protection, 49(9), 696-705. https://doi.org/10.4315/0362-028X-49.9.696

ISO 4833-1. (2013). Microbiology of the food chain-Horizontal method for the enumeration of microorganisms-Part 1: Colony count at 30 degrees $\mathrm{C}$ by the pour plate technique, https://www. iso.org/standard/53728.html (accessed on July 20, 2019)

Martini, S. (2013). Common Uses of Power Ultrasound in the Food Industry. In S. Martini (Ed.), Sonocrystallization of Fats (pp. 27-33). Springer. https://doi.org/10.1007/978-1-4614-7693-1-4

McSweeney, P. L. H., \& Fox, P. F. (2009). Significance of Lactose in Dairy Products. In P. McSweeney \& P. F. Fox (Eds.), Advanced Dairy Chemistry: Volume 3: Lactose, Water, Salts and Minor Constituents (pp. 35-104). Springer. https://doi.org/10.1007/978-0-387-84865-5_3

Milly, P.J., Toledo, R.T., Kerr, W., \& Armstead, D. (2008). Hydrodynamic cavitation: characterization of a novel design with energy considerations for the inactivation of Saccharomyces cerevisiae in apple juice. Journal of Food Science, 73, M298-303. https://doi.org/10.1111/j.17503841.2008.00827.x

Milly, P., Toledo, R., Harrison, M., \& Armstead, D. (2007). Inactivation of food spoilage microorganisms by hydrodynamic cavitation to achieve pasteurization and sterilization of fluid foods. Journal of Food Science, 72, M414-22. https://doi.org/10.1111/j.1750-3841.2007.00543.x

Munir, M., Nadeem, M., Qureshi, T. M., Leong, T. S. H., Gamlath, C. J., Martin, G.J.O., \& Ashokkumar, M. (2019). Effects of high pressure, microwave and ultrasound processing on proteins and enzyme activity in dairy systems-A review. Innovative Food Science and Emerging Technologies, 57, 102197

Nguyen, N.H.A., \& Anema, S.G. (2017). Ultrasonication of reconstituted whole milk and its effect on acid gelation. Food Chemistry, 217, 593-601. https://doi.org/10.1016/j.foodchem.2016.08.117

Pegu, K., \& Arya, S. S. (2021). Comparative assessment of HTST, hydrodynamic cavitation and ultrasonication on physicochemical properties, microstructure, microbial and enzyme inactivation of raw milk. Innovative Food Science \& Emerging Technologies, 69,102640 https://doi.org/10.1016/j.ifset.2021.102640

Prasantha, B.D.R., \& Wimalasiri, K.M.S. (2019). Effect of HTST thermal treatments on end-use quality characteristics of goat milk. International Journal of Food Science, 2019, 1801724. https://doi.org/10.1155/2019/1801724

Salve, A.R., Pegu, K., \& Arya, S.S. (2019). Comparative assessment of high-intensity ultrasound and hydrodynamic cavitation processing on physico-chemical properties and microbial inactivation of peanut milk. Ultrasonics Sonochemistry, $\quad 59,104728$. https://doi.org/10.1016/j.ultsonch.2019.104728

Shamsi, K., Versteeg, C., Sherkat, F., \& Wan, J. (2008). Alkaline phosphatase and microbial inactivation by pulsed electric field in bovine milk. Innovative Food Science \& Emerging Technologies, 9 217-223. https://doi.org/10.1016/j.ifset.2007.06.012

Tao, N., Liu, Y., \& Zhang, M. (2009). Chemical composition and antimicrobial activities of essential oil from the peel of bingtang sweet orange (Citrus sinensis Osbeck). International Journal of Food Science \& Technology, 44, 1281-1285. https://doi.org/10.1111/j.1365-2621.2009.01947.x 